\title{
Magnetic resonance imaging
}

\author{
Clara Malattia ${ }^{1,2}$ \\ From 21st European Pediatric Rheumatology (PReS) Congress \\ Belgrade, Serbia. 17-21 September 2014
}

MR imaging is encountering an expanding application in the assessment of patients with paediatric chronic rheumatic diseases. By providing multiplanar tomographic imaging with unparallel soft tissue contrast, MRI allows the simultaneous evaluation of all joint structures involved in inflammatory arthritis and it is regarded as one of the most attractive imaging modalities for the investigation of juvenile idiopathic arthritis (JIA). MRI provides additional and more sensitive information over clinical examination and other imaging modalities and holds great promise in supporting diagnosis of JIA, assessing its severity and prognosis, monitoring disease course and treatment efficacy.

The use of MRI in the assessment of the musculoskeletal system in children has important differences from its adult counterpart. Growing joints change anatomically over time making imaging in JIA a real challenge without the availability of normative data. A sound knowledge of growth-related changes, in fact, is of foremost value to establish whether joint surface changes reflect a real damage or are actually part of normal development.

Main indications for musculoskeletal MRI in paediatric rheumatology, technical issues and diagnostic accuracy, pitfalls in image analysis and newer MRI and scanner techniques (i.e whole-body MRI) will be discussed thus providing an overview of the recent advances and challenging in imaging children with rheumatic disorders.

\section{Disclosure of interest}

None declared.

Authors' details

${ }^{1}$ Pediatrics, University of Genova, Italy. ${ }^{2}$ Peditria II Reumatologia, Istituto

Giannina Gaslini, Genova, Italy.

Published: 17 September 2014

${ }^{1}$ Pediatrics, University of Genova, Italy

Full list of author information is available at the end of the article
doi:10.1186/1546-0096-12-S1-123

Cite this article as: Malattia: Magnetic resonance imaging. Pediatric

Rheumatology 2014 12(Suppl 1):123.
Submit your next manuscript to BioMed Central and take full advantage of:

- Convenient online submission

- Thorough peer review

- No space constraints or color figure charges

- Immediate publication on acceptance

- Inclusion in PubMed, CAS, Scopus and Google Scholar

- Research which is freely available for redistribution
() Biomed Central

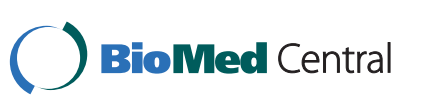

